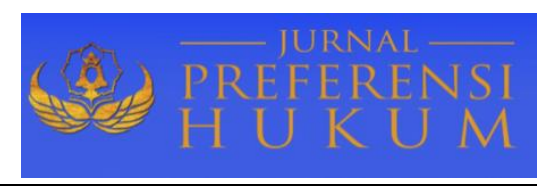

Jurnal Preferensi Hukum | ISSN: XXXX | E-ISSN: XXXX

Vol. 1, No. 2 - September 2020, Hal. 201-207| Available Online at https://www.ejournal.warmadewa.ac.id/index.php/juprehum

DOI: http://doi.org/10.22225/jph.v1i2.2390. 201-207

\title{
SANKSI TERHADAP PENYALAHGUNAAN PEMAKAIAN LISTRIK DI WILAYAH PERUSAHAAN LISTRIK NEGARA (PERSERO) RAYON KUTA
}

\author{
I Made Ariana, Ida Ayu Putu Widiati, A.A Sagung Laksmi Dewi \\ Fakultas Hukum Universitas Warmadewa, Denpasar-Bali, Indonesia
}

\begin{abstract}
Abtsrak
Hubungan antara PT. PLN (Persero) dan pengguna tenaga listrik adalah jual beli yang ketentuannya diatur dalam surat perjanjian Jual Beli Tenaga Listrik (SPJBTL). Berdasarkan fenomena yang terjadi, permasalahan penyalahgunaan penggunaan listrik khususnya yang terjadi dalam tiga tahun terakhir di wilayah pelayanan PLN Rayon Kuta sangat merugikan negara dalam hal ini PLN. Penelitian ini mengungkap faktor-faktor penyebab penyalahgunaan penggunaan listrik dan penerapan sanksi terhadap penyalahgunaan listrik di PT. PLN (Persero) Rayon Kuta dengan metode penelitian hukum empiris. Penyalahgunaan listrik di Kuta dan sekitarnya dilatarbelakangi oleh beberapa faktor antara lain ketidaktahuan, niat, pelanggan eksternal dan kelalaian pelanggan. Dari beberapa bukti fisik yang ditemukan oleh T2 P2TL PT. PLN (Persero) Kuta rayon, beberapa bentuk penyalahgunaan konsumsi listrik dapat dikategorikan antara lain seperti mempengaruhi hambatan listrik, pengukuran, dan sambungan liar diluar pengukuran. Dalam kasus penyelesaian penyalahgunaan penggunaan listrik, PLN menggunakan dasar hukum peraturan direksi PT. PLN (Persero) Nomor: 088-Z.P / DIR / 2016 tentang Pengendalian Penggunaan Tenaga Listrik. Untuk meminimalisir terjadinya penyalahgunaan penggunaan listrik, maka perlu optimalisasi sosialisasi terkait penggunaan listrik yang benar dan aman oleh PLN bekerja sama dengan pihak terkait lainnya seperti pendidikan tingkat universitas, lingkungan atau perangkat desa dan khususnya di Bali PT. PLN harus bekerja sama dengan pengurus atau kelian (ketua kelompok adat banjar) dengan mekanisme tertentu. Penerapan sanksi kepada pelanggan atau pengguna PLN yang kedapatan menyalahgunakan listrik perlu memperhatikan manfaat hukumnya, terutama yang terbukti melanggar Kategori IV agar proses penyelesaian melalui ranah hukum dapat menimbulkan efek jera. Akibatnya di masa mendatang kejadian serupa yang berdampak pada kerugian negara dan kerugian masyarakat lainnya sebagai pengguna listrik dapat dikurangi atau diminimalisir.
\end{abstract}

Kata Kunci: Kontrol; Pelanggan; Pelanggaran

\begin{abstract}
The relationship between PT. PLN (Persero) and the electricity user is a selling and purchasing whose provisions are set forth in an agreement called Surat Perjanjian Jual Beli Tenaga Listrik (SPJBTL). Based on the occurring phenomenon, the problem of abuse of electricity usage, especially that occurred in the last three years in the service area of PLN Rayon Kuta, is extremely detrimental to the state in this case the PLN. This study reveals the factors that lead to misuse of electricity usage and the application of sanctions against misuse of electricity in the PT. PLN (Persero) Rayon Kuta with empirical legal research. The abuse of the electricity in Kuta and its surrounding areas are motivated by several factors including ignorance, intention, external customer and customer negligence. From some of the physical evidence found by T2 P2TL PT. PLN (Persero) Kuta rayon, several forms of abuse of electricity consumption can be categorized, among others such as affect power barriers, measurement, and wild connection outside the measurement. In the case of the settlement of the abuse of the electricity usage, PLN uses the legal basis of the regulation of directors of PT. PLN (Persero) Number: 088-Z.P / DIR / 2016 concerning the Controlling of Electricity Usage. To minimize the occurrence of abuse of electricity usage, it is necessary to optimize socialization related to the right and safe electricity usage by PLN in cooperation with other related parties such as university level education, environment or village apparatus and especially in Bali the PT. PLN should cooperate with the management or kelian (the leader of a customary group of community called banjar) under certain mechanism. The application of sanctions to PLN customers or users who are found to be abusing the use of electricity need to consider the legal benefit, especially those found to violate Category IV in order to make the process of settlement through the legal sphere
\end{abstract}


to create a deterrent effect so that in the future similar incidents affecting the state losses and other public losses as electricity users can be reduced or minimized.

Keywords: Customer; Violation; Control

\section{PENDAHULUAN}

Negara Indonesia adalah negara hukum, demikian bunyi Pasal 1 Ayat (3) Undang-undang Dasar Negara Republik Indonesia tahun 1945, perubahan ketiga. Hal ini mengandung arti bahwa dalam setiap penyelenggaraan negara haruslah tetap berdasarkan pada aturan hukum yang berlaku, dengan kata lain hukum dijadikan supremasi tertinggi dalam negara. Negara mempunyai tanggungjawab besar untuk mensejahterakan rakyatnya melalui instrumen hukum itu sendiri (Ridwan, 2003; Atmadjaja, 2011; Sumardi \& Zulpahmi, 2017). Pemerintah akan melakukan segala cara dan upaya di antaranya melalui penciptaan norma-norma sebagai dasar pelaksanaan menjalankan kegiatan pemerintahan dan melaksanakan kegiatan pembangunan demi terwujudnya masyarakat yang sejahtera, adil dan makmur.

Sesuai Pasal 33 Ayat (2) Undang-Undang Dasar Negara Republik Indonesia Tahun 1945 yang menyebutkan "Cabang-cabang produksi yang penting bagi negara dan yang menguasai hajat hidup orang banyak dikuasai oleh negara",maka tepatlah jika negara dalam hal ini sudah memikirkan untuk mewujudkan rasa adil dan kesejahteraan masyarakat. Demikian pula halnya dengan listrik yang merupakan kebutuhan penting bagi seluruh masyarakt Indonesia pengaturannya berada dalam kendali pemerintah atau negara. Hal tersebut bertujuan untuk menjamin ketersediaan listrik yang memadai dan penyaluran energi listrik yang merata sehingga bisa dirasakan manfaatnya oleh seluruh lapisan masyarakat Indonesia (Mujiyanto dkk., 2016). Dalam menjalankan kewajiban menyediakan tenaga listrik bagi masyarakat, pemerintah menugaskan Badan Usaha Milik Negara (BUMN) untuk memenuhi kebutuhan tersebut.

Regulasi yang mengatur tentang kelistrikan di Indonesia yang berlaku positif saat ini adalah Undang-Undang Nomor 30 Tahun 2009 tentang Ketenagalistrikan. Menurut ketentuan Pasal 11 Undang-Undang Nomor 30 Tahun 2009 tentang Ketenagalistrikan tersebut, PT. PLN (Persero) memiliki tugas utama melaksanakan usaha penyediaan tenaga listrik untuk kepentingan umum. Hal ini sejalan dengan tujuan nasional negara Indonesia seperti yang tertuang dalam Pembukaan Undang-Undang Dasar Negara Republik Indonesia Tahun 1945 Alinea Keempat, khususnya untuk ikut memajukan kesejahteraan umum dan mencerdaskan kehidupan bangsa.

Di samping ketentuan terkait kewajiban sebagai pemegang izin usaha penyediaan tenaga listrik, Undang-undang nomor 30 tahun 2009 tentang ketenagalistrikan juga mengatur tentang hak pemegang izin usaha penyediaan tenaga listrik. Masyarakat sebagai pengguna listrik yang dalam hal ini disebut konsumen, juga harus tunduk kepada Undang-Undang Nomor 30 Tahun 2009 tentang ketenagalistrikan. Dimana dalam Undang-Undang Nomor 30 Tahun 2009 tentang ketenagalistrikan tersebut juga diatur tentang hak dan kewajiban selaku konsumen.

Hubungan jual-beli antara PT. PLN (Persero) dengan masyarakat pengguna listrik dituangkan secara terperinci dalam sebuah surat perjanjian yang disebut SPJBTL. Dalam hal hubungan jual-beli, setiap pelanggan listrik PLN terikat dengan peraturan atau ketentuan yang dituangkan dalam Surat Perjanjian Jual Beli Tenaga Listrik (SPJBTL) tersebut. Surat Perjanjian Jual Beli Tenaga Listrik antara PT. PLN (Persero) dengan pelanggannya berbentuk surat perjanjian standard. Perjanjian standard umum ialah perjanjian yang bentuk dan isinya telah dipersiapkan terlebih dahulu oleh pihak tertentu yang membuat perjanjian kemudian disodorkan pada pihak lain yang akan mengikatkan diri dalam perjanjian tersebut. Idealnya para pihak membaca klausula-klausula perjanjian terlebih dahulu sebelum memutuskan untuk menyepakatinya, artinya seluruh ketentuan dalam perjanjian tersebut sudah dipahami. Akan tetapi dalam pelaksanaannya seringkali kita jumpai bahwa masyarakat selaku konsumen masih banyak yang kurang memahami isi perjanjian maupun konsekuensinya jika melanggar ketentuan-ketentuan yang termuat didalam klausula surat perjanjian jual beli tenaga listrik tersebut. Hal ini menyebabkan sering terjadi pelanggaran-pelanggaran atau perbuatanperbuatan yang bertentangan dengan ketentuan perjanjian karena ketidaktahuannya.

Walaupun pemerintah dalam hal ini sudah menetapkan regulasi yang mengatur tentang ketenagalistrikan serta regulasi yang mengatur tentang perlindungan konsumen yang di dalamnya terdapat ketentuan tentang hak dan kewajiban serta konsekuensi terhadap pelanggarannya, akan tetapi masih ada saja masyarakat selaku pelanggan dan atau pengguna listrik khususnya, terjerat atau 
terjerumus dalam permasalahan hukum terkait penyalahgunaan pemakaian tenaga listrik. Berdasarkan fenomena yang terjadi, permasalahan penyalahgunaan pemakaian tenaga listrik khususnya yang terjadi dalam tiga tahun terakhir di wilayah pelayanan PLN rayon Kuta, jika dilihat dari sisi dampak kerugiannya sudah barang tentu sangat merugikan negara dalam hal ini PLN.

Masyarakat sebagai pihak pengguna listrik PLN, yang karena ketidaktahuannya terpaksa harus mempertanggungjawabkan kejadian penyalahgunaan pemakaian tenaga listrik akan merasa diperlakukan secara tidak adil oleh negara yang dalam hal ini adalah pihak PLN. Hal tersebut sering terjadi pada pelanggan yang baru melakukan proses pembelian properti atau bangunan di mana sebelumnya telah terdapat $\mathrm{kWh}$ meter dengan kondisi tidak normal akibat dilakukan tindakan penyalahgunaan oleh pemilik bangunan yang lama sementara baru ditemukan oleh Tim P2TL PLN di saat bangunan tersebut telah ditempati oleh pemilik yang baru.

Kejadian penyalahgunaan pemakaian tenaga listrik dengan cara-cara tertentu akan berdampak pada kerugian masyarakat lainnya karena bisa menyebabkan rusaknya peralatan atau infrastruktur jaringan yang berfungsi untuk mendistribusikan tanaga listrik secara meluas, sehingga berpotensi meyebabkan listrik padam. Padamnya listrik yang disebabkan oleh perbuatan penyalahgunaan pemakaian tenaga listrik yang terjadi dalam jangka waktu yang lama akan berdampak kepada kerugian di sektor perekonomian,keamanan dan pariwisata, terlebih-lebih kejadian tersebut terjadinya diwilayah Kuta yang merupakan basis pariwisata pulau Bali.

Berdasarkan latar belakang masalah tersebut, rumusan masalah kajian ini adalah: (1) apa sajakah faktor-faktor yang menyebabkan terjadinya penyalahgunaan pemakaian listrik? (2) Bagaimana penerapan sanksi terhadap penyalahgunaan pemakaian listrik di Wilayah PT. PLN (Persero) Rayon Kuta? Adapun tujuan kajian ini secara umum antara lain untuk mengetahui dan memahami faktafakta hukum yang ada dilingkungan masyarakat, mengetahui dan memahami ketentuan hukum positif dan atau ketentuan hukum khusus yang mengatur mengenai fakta-fakta hukum dan untuk memperluas serta memperdalam pemahaman dalam memberikan penjelasan hukum maupun logika hukum pada fakta-fakta yang ada sesuai ketentuan. Sedangkan tujuan khusus kajian ini adalah antara lain untuk mengetahui faktor-faktor penyebab terjadinya penyalahgunaan pemakaian listrik dan mengetahui penerapan sanksi terhadap penyalahgunaan pemakaian listrik di Wilayah PT. PLN (Persero) Rayon Kuta.

\section{METODE PENELITIAN}

Penelitian mempunyai berbagai kategori. Berdasarkan pada fokus kajiannya metode penelitian terbagi menjadi tiga bagian yakni: metode penelitian hukum normatif, metode penelitian hukum normatifempiris dan metode penelitian hukum empiris (Johan, 2008). Kajian ini menggunakan metode penelitian hukum empiris. Data penelitian berbentuk data primer dan data sekunder. Data primer berupa undang-undang atau pengaturan hukum terkait dengan listrik dan penyalahgunaan daya. Data sekunder meliputi teori-teori yang berkaitan dengan kajian tentang listrik dan penyalahgunaan dayanya, yang diperoleh dari buku, artikel jurnal, dan sumber-sumber lain yang mempunyai kaitan erat dengan kaitan ini. Data dari kedua jenis tersebut dikumpulkan menggunakan teknik dokumentasi, yang meliputi pencarian dan pengumpulan. Data dianalisis dengan membaca dan memahaminya, kemudian mengkategorikan menurut jenis yang sama dan menjelaskannya dengan mengaitkan dengan objek kajian penelitian ini.

\section{HASIL DAN PEMBAHASAN}

Penyalahgunaan pemakaian listrik merupakan tindakan melanggar hukum (Andrisman, 2009; Widiyati, 2012; Rusianto, 2015). Baik disadari ataupun tidak, ketika ditemukan bukti fisik yang berdampak pada kerugian negara atas penggunaan energi listrik yang dilakukan oleh pihak tertentu tanpa alas hak yang sah, maka dengan dasar ketentuan Undang-undang perbuatan atau kondisi tersebut sudah dikatagorikan sebagai perbuatan melawan hukum yang sudah tentu ada konsekuensinya berupa sanksi (Pemakai, 2014).

Sebagai negara hukum, Indonesia sangat memegang teguh asas legalitas dalam segala aspek. Hukum dijadikan supremasi tertinggi dalam kehidupan bernegara. Manusia sebagai makhluk sosial yang hidup bermasyarakat, di mana dalam kesehariannya selalu bergaul dan berinteraksi antar individu dan antar kelompok satu dengan kelompok lainnya, tentu akan terjadi saling mempengaruhi. 
Hal itu akan berdampak pada perilaku atau perbuatan yang dilakukannya. Perilaku seseorang yang dipengaruhi oleh lingkungan yang bersifat negatif tentunya akan menjurus kepada pelanggaran hukum. Hal ini juga terjadi pada prilaku dalam menggunakan listrik.

Setiap energi listrik yang digunakan dalam jumlah tertentu harus dibayar sesuai dengan jumlah pemakaiannya. Karena kondisi perekonomian dewasa ini yang semakin sulit membuat sebagian orang berfikir untuk berupaya melakukan penghematan disisi pengeluaran, salah satu penghematan yang bisa dilakukan adalah disisi pengeluaran biaya listrik, terlebih lagi jika kita melihat dikalangan usahausaha yang notabene menggunakan tenaga listrik sebagai penggerak operasional, misalnya seperti usaha loundry, cold storage untuk usaha pengalengan ikan, usaha tambak ikan dan usaha hotel atau penginapan , jika berhasil dilakukan penghematan pengeluaran atas biaya listrik akan meningkatkan margin keuntungan atas usaha tersebut.

Dari hasil wawancara yang penulis lakukan dengan bapak Dwiyono Hadi Saputro, selaku koordinator lapangan Tim Penertiban Pemakaian Tenaga Listrik (P2TL) PT. PLN (Persero) Rayon Kuta, diantara pelanggan-pelanggan yang kedapatan melakukan penyalahgunaan pemakaian tenaga listrik di daerah Kuta dan sekitarnya, dilatarbelakangi oleh beberapa faktor antara lain: faktor ketidaktahuan atau kurang paham tentang batas-batas hak dan kewenangan serta batas tanggungjawab, antara pihak PLN dengan pihak pelanggan, niat dengan sengaja karena didorong oleh keinginan untuk menggunakan listrik banyak dan membayar sedikit, eksternal pelanggan, biasanya dilakukan oleh oknum tertentu,kelalaian pelanggan dalam menjaga $\mathrm{kWh}$ meter yang terpasang di persil pelanggan.

Berdasarkan informasi hasil wawancara yang dilakukan penulis kepada bapak Agus Dharmika, selaku pejabat Supervisor Transaksi Energi di PT. PLN (Persero) Rayon Kuta, perbuatan pelanggaran dan penyalahgunaan pemakaian listrik di wilayah pelayanan PT. PLN (Persero) Rayon Kuta selama 3 (tiga) tahun terakhir berpotensi sangat besar merugikan negara.

Berdasarkan data dalam 3 (tiga) tahun terakhir, perkembangan temuan atas kegiatan P2TL terkait penyalahgunaan pemakaian tenaga listrik di wilayah PLN rayon Kuta, dari total jumlah temuan pelanggan yang kedapatan melakukan penyalahgunaan pemakaian listrik sejumlah 2.748 pelanggan, dengan total jumlah $\mathrm{kWh}$ yang disalahgunakan $18.711 .276 \mathrm{kWh}$, dapat diketahui bahwa akibat tindakan tersebut, negara dalam hal ini PLN dirugikan secara pendapatan sejumlah Rp. 28.240.417.786,- Dari beberapa bukti fisik yang ditemukan oleh TIM P2TL selama melaksanakan kegiatan dalam rangka Penertiban Pemakaian Tenaga Listrik di Wilayah PT. PLN (Persero) rayon Kuta, dapat dikatagorikan beberapa bentuk penyalahgunaan pemakaian listrik, antara lain: mempengaruhi pembatas daya (Katagori Pelanggaran P1), mempengaruhi pengukuran (Katagori Pelanggaran P2), mempengaruhi pengukuran dan pembatas daya (Katagori Pelanggaran P3) dan penyambungan liar diluar pengukuran (Katagori Pelanggaran P4).

Penyalahgunaan pemakaian tenaga listrik dengan cara-cara tertentu akan berdampak pada kerugian negara dan juga kerugian bagi masyarakat luas, disamping itu perbuatan penyalahgunaan pemakaian tenaga listrik juga berpotensi terhadap bahaya, baik bagi pelaku, lingkungan sekitar maupun terhadap aset dan atau bangunan beserta isinya. Potensi bahaya yang bisa ditimbulkan akibat penyalahgunaan pemakaian tenaga listrik adalah bahaya terhadap tegangan sentuh bagi pelaku dan lingkungan sekitar, disamping itu juga bisa berpotensi bahaya terhadap aset atau bangunan beserta isinya karena bisa menyebabkan kebakaran akibat listrik yang penyambungannya tidak sesuai standar.

Di samping ketentuan yang diatur dalam Undang-undang ketenagalistrikan, jika kedapatan konsumen atau pelanggan listrik melakukan penyalahgunaan pemakaian tenaga listrik, dengan mengacu kepada surat perjanjian jual beli tenaga listrik (SPJBTL) yang ada antara pihak PLN dengan pihak pelanggan, pihak PLN bisa melakukan pemutusan penyaluran tenaga listrik secara sepihak dan meminta pertanggungjawaban dari pihak konsumen atau pelanggan sesuai ketentuan berdasarkan kriteria pelanggaran yang dilakukan.

Dalam hal penyelesaian perselisihan secara musyawarah terhadap penyalahgunaan pemakaian listrik, PLN menggunakan dasar hukum yang merupakan ketentuan internal perusahaan yang dikeluarkan oleh direksi yaitu: Peraturan direksi PT. PLN (Persero) nomor 088-Z.P/DIR/2016 tentang Penertiban pemakaian tenaga listrik. Dalam peraturan direksi tersebut telah dituangkan atau ditentukan sanksi-sanksi administratif sesuai katagori pelanggaran yang terjadi berdasarkan hasil temuan TIM P2TL PLN yang dituangkan dalam berita acara pemeriksaan P2TL. 
Ketentuan jenis dan golongan pelanggaran pemakaian tenaga listrik di atur dalam Bab VII Pasal 13 Peraturan Direksi PT. PLN (Persero) Nomor: 088-ZP/DIR/2016 Tahun 2016, tentang Penertiban Pemakaian Tenaga Listrik, dengan ketentuan terdapat 4 (empat) golongan pelanggaran atau penyalahgunaan pemakaian tenaga listrik, yaitu:

1. Pelanggaran Golongan I (P I) merupakan pelanggaran yang mempengaruhi batas daya tetapi tidak mempengaruhi pengukuran energi;

2. Pelanggaran Golongan II (P II) merupakan pelanggaran yang mempengaruhi pengukuran energi tetapi tidak mempengaruhi batas daya;

3. Pelanggaran Golongan III (P III) merupakan pelanggaran yang mempengaruhi batas daya dan mempengaruhi pengukuran energi;

4. Pelanggaran Golongan IV (P IV) merupakan pelanggaran yang dilakukan oleh bukan pelanggan yang menggunakan tenaga listrik tanpa alas hak yang sah.

Ketentuan mengenai sanksi pelanggaran terhadap pemakaian tenaga listrik diatur di dalam Bab VIII Pasal 14 Peraturan Direksi PT. PLN (Persero) Nomor: 088-ZP/DIR/2016 Tahun 2016, tentang Penertiban Pemakaian Tenaga Listrik pada bagian kesatu "Sanksi P2TL", dengan ketentuan sebagai berikut:

1. Pelanggan yang melakukan pelanggaran sebagaimana dimaksud dalam Pasal 13 dikenakan sanksi berupa: Pemutusan sementara, pembongkaran rampung, pembayaran Tagihan Susulan (TS) dan pembayaran Biaya P2TL lainnya.

2. Bukan pelanggan, yang terkena P2TL dikenakan sanksi berupa: Pembongkaran rampung, pembayaran TS4, pembayaran P2TL lainnya.

3. Pelanggan atau bukan pelanggan yang melakukan pelanggaran dan tidak menyelesaikan TS (Tagihan Susulan) sesuai golongan pelanggarannya, namun menyambung kembali aliran listrik ke satuan instalasi yang bermasalah secara tidak sah,maka akan dikenakan P2TL ulang dengan TS ganda.

4. Pelanggan yang melakukan pelanggaran P I, lebih dari 1 (satu) kali, pelanggan tersebut diwajibkan tambah daya bersamaan dengan penyelesaian TS.

5. Dalam hal pelanggan sebagaimana dimaksud pada ayat (3) dan (4) tidak menyelesaikan TS dan tambah daya tersebut, maka akan dilakukan pemutusan / pembongkaran rampung atas tenaga listrik tersebut.

6. Sebagaimana ketentuan yang berlaku secara umum di PT. PLN (Persero), setiap kedapatan penyalahgunaan pemakaian listrik diupayakan penyelesaiannya dengan jalur administrasi diluar ranah pengadilan.

Pelanggan atau pengguna listrik yang kedapatan melakukan pelanggaran penyalahgunaan pemakaian listrik, sesuai pasal 14 Peraturan Direksi PT. PLN (Persero) nomor: 088-ZP/DIR/2016 tahun 2016, tentang Penertiban Pemakaian Tenaga Listrik, dikenakan sanksi berupa:Pemutusan sementara aliran listrik, pembongkaran rampung peralatan listrik, pembayaran Tagihan Sususlan (TS), pembayaran biaya P2TL lainnya.

Untuk katagori pelanggaran P1, P2 dan P3 tagihan susulannya bisa diselesaikan dengan cara mencicil atau mengangsur sesuai kesepakatan kedua belah pihak. Sedangkan untuk katagori pelanggaran P4 tagihan susulan harus diselesaikan dengan sekali pembayaran (sekali pelunasan). Jika pihak pelanggan atau pengguna listrik tidak bersedia menyelesaikan secara administrasi, maka pihak PLN bisa membawa permasalahan temuan P2TL tersebut ke ranah hukum.

\section{SIMPULAN DAN SARAN}

\section{Simpulan}

Dari hasil penelitian melalui wawancara yang penulis lakukan dapat ditarik kesimpulan sebagai berkut:

1. Perbuatan penyalahgunaan pemakaian tenaga listrik oleh pelanggan PLN, dilatarbelakangi oleh beberapa faktor antara lain:Ketidaktahuan atau kurang paham tentang batas-batas hak dan tanggungjawab sebagai pelanggan listrik, niat dengan sengaja karena didorong oleh keinginan untuk menggunakan listrik banyak dengan kewajiban membayar sedikit, faktor external pelanggan yang dilakukan oleh oknum tertentu untuk mencari keuntungan dengan cara menjanjikan bahwa yang bersangkutan bisa menghemat pengeluaran biaya listrik 
pelanggan dan kelalaian pelanggan dalam menjaga $\mathrm{kWh}$ meter yang terpasang di persil pelanggan sehingga ada orang lain yang dengan sengaja melakukan modifikasi pada $\mathrm{kWh}$ meter dan perlengkapannya tersebut untuk keuntungan pribadi,biasanya terjadi pada pelanggan-pelanggan sementara atau layanan listrik sementara dimana persil yang terpasang listrik masih dalam tahap proses pembangunan atau proyek dan orang yang melakukan modifikasi pada $\mathrm{kWh}$ meter tersebut biasanya pekerja-pekerja proyek bangunan tersebut untuk kepentingan operasional peralatan kerja, dan sering juga terjadi pada pelanggan listrik untuk rumah sewa atau rumah kos-kosan.

2. Dari beberapa bukti fisik yang ditemukan oleh TIM P2TL di Wilayah PT. PLN (Persero) rayon Kuta, dapat dikatagorikan beberapa bentuk penyalahgunaan pemakaian listrik, antara lain:Mempengaruhi pembatas daya (Katagori Pelanggaran P1), mempengaruhi pengukuran (Katagori Pelanggaran P2), mempengaruhi pengukuran dan pembatas daya (Katagori Pelanggaran P3) dan penyambungan liar diluar pengukuran (Katagori Pelanggaran P4).

3. Penyalahgunaan pemakaian tenaga listrik dengan cara- cara tertentu akan berdampak pada kerugian negara dan juga kerugian bagi masyarakat luas, disamping itu perbuatan penyalahgunaan pemakaian tenaga listrik juga berpotensi bahaya, bagi pelaku, lingkungan sekitar maupun terhadap aset dan atau bangunan beserta isinya. Dampak kerugian bagi masyarakat luas bisa terjadi karena peralatan-peralatan untuk mendistribusikan tenaga listrik ke seluruh masyarakat seperti trafo dan atau gardu beserta kabel jaringan tegangan rendah bisa menjadi rusak akibat beban listrik yang berlebih diluar kapasitas peralatan tersebut yang disebabkan oleh energi yang disalurkan tidak bisa diketahui karena tidak terukur dengan baik akibat penyalahgunaan pemakaian listrik tersebut.

4. Jika kedapatan melakukan perbuatan penyalahgunaan pemakaian tenaga listrik, maka sesuai ketentuan didalam surat perjanjian jual beli tenaga listrik (SPJBTL) antara PLN dengan pelanggan, pihak PLN mengutamakan penyelesaian secara administratif dengan menggunakan dasar hukum Peraturan direksi PT. PLN (Persero) nomor 088-Z.P/DIR/2016 tahun 2016, tentang Penertiban pemakaian tenaga listrik,dengan sanksi sesuai ketentuan dalam Bab VIII Pasal 14, antara lain berupa:Pemutusan sementara aliran listrik,pembongkaran rampung peralatan listrik, Pembayaran Tagihan Susulan (TS) dan pembayaran biaya P2TL lainnya.

5. Untuk katagori pelanggaran $\mathrm{P} 1, \mathrm{P} 2$ dan $\mathrm{P} 3$ tagihan susulannya bisa diselesaikan dengan cara mencicil atau mengangsur sesuai kesepakatan kedua belah pihak. Sedangkan untuk katagori pelanggaran P4 tagihan susulan harus diselesaikan dengan sekali pembayaran (sekali pelunasan). Akan tetapi Jika pihak pelanggan atau pengguna listrik tidak bersedia menyelesaikan secara administrasi, maka pihak PLN akan membawa permasalahan temuan P2TL tersebut ke ranah hukum dengan melaporkan kasus tersebut ke kejaksaan negeri setempat, untuk selanjutnya diupayakan penyelesaian sesuai ketentuan hukum yang berlaku.

\section{Saran}

Berdasarkan permasalahan dan hasil penelitian serta kesimpulan yang didapat, penulis memberikan saran-saran sebagai berikut:

1. Karena pada umumnya masyarakat sebagai pengguna listrik PLN kebanyakan masih awam pengetahuannya terhadap hal-hal yang berkaitan dengan ilmu listrik maupun batas-batas hak dan kewajiban sebagai pelanggan, maka untuk meminimalisir terjadinya penyalahgunaan pemakaian tenaga listrik terutama yang disebabkan oleh faktor ketidaktahuan, faktor external pelanggan dan faktor kelalaian pelanggan maka pihak PLN perlu lebih mengoptimalkan sosialisasi yang berkaitan dengan penggunaan listrik yang benar dan aman, bekerjasama dengan pihak lainnya yang terkait seperti kalangan dunia pendidikan setingkat perguruan tinggi, aparat lingkungan atau desa dan khususnya di Bali bisa menggandeng pihak pengurus atau kelian banjar setempat.

2. Dalam hal penerapan sanksi kepada pelanggan atau pengguna listrik PLN yang kedapatan melakukan penyalahgunaan pemakaian tenaga listrik, perlu lebih dipertimbangkan sisi kemanfaatan hukumnya, khususnya yang kedapatan melakukan pelanggaran katagori PIV agar dilakukan proses penyelesaian melalui ranah hukum, untuk menimbulkan efek jera 
sehingga kedepannya bisa mengurangi atau meminimalisir kejadian serupa yang berdampak pada kerugian negara dan kerugian masyarakat umum lainnya selaku pengguna listrik, karena jenis pelanggaran katagori PIV bisa menyebabkan rusaknya infrastruktur jaringan PLN sehingga menimbulkan padamnya listrik secara meluas yang dapat merusak citra pariwisata.

\section{DAFTAR PUSTAKA}

Andrisman, T. (2009). Asas-Asas dan Dasar Aturan Hukum Pidana Indonesia. Unila.

Atmadjaja, D. I. (2011). Membangun Hukum untuk Kesejahteraan. Jurnal Konstitusi, 4(2), 16-35.

Johan, B. (2008). Metode Penelitian Ilmu Hukum. Mandar Maju.

Mujiyanto, S., Supriadi, A., Darmawan, A., Prasetyo, B. E., Kurniasih, T. N., Oktaviani, K., Aprilia, R., Rabbani, Q., Anggreani, D., \& Setiadi, I. (2016). Manajemen Rantai Penyediaan dan Pemanfaatan Energi Nasional. Pusat Data dan Teknologi Informasi Kementerian Energi dan Sumber Daya Mineral.

Pemakai, B. H. A. K. (2014). Penegakan Hukum Terkait Pemakaian Tenaga Listrik yang Bukan Hak Pemakai. Kumpulan Jurnal Mahasiswa Fakultas Hukum Universitas Brawijaya, 1-17.

Ridwan. (2003). Pertanggungjawaban Publik Pemerintah dalam Perspektif Hukum Administrasi Negara. Jurnal Hukum, 10(22), 27-38.

Rusianto, A. (2015). Tindak Pidana dan Pertanggungjawaban Pidana Tinjauan Kritis melalui Konsistensi antara Asas, Teori, Penerapannya. PT. Fajar Interpratama Mandiri.

Sumardi, \& Zulpahmi. (2017). Peran Negara untuk Mewujudkan Kesejahteraan dalam Kerangka Maqashidus Syariah. Al-Urban: Jurnal Ekonomi Syariah Dan Filantropi Islam, 2(1), 155-175.

Widiyati, M. (2012). Implementasi Program Penertiban Pemakaian Tenaga Listrik (P2TL) PT PLN (Persero) Distribusi Jawa Tengah dan DI Yogyakarta di Kota Semarang [Universitas Diponegoro]. 